DOI https://doi.org/10.30525/978-9934-26-073-5-1-24

\title{
ТИПИ МАНДРІВНИХ ЛЮДЕЙ В «ЕНЕЇДІ» І. КОТЛЯРЕВСЬКОГО
}

\author{
Білоус Б. П. \\ кандидат філологічних наук, \\ дочент кафедри теоретичної та прикладної лінгвістики \\ Державного університету «Житомирська політехніка» \\ м. Житомир, Украӥна
}

Українське XVIII ст., в умовах якого сформувалося художне світовідчуття Котляревського, було досить "рухливим" - ця динаміка виявила себе на рівні історико-суспільному, на рівні філософських та соціокультурних пошуків, на рівні естетичних зрушень. Відтак "Енеїда" постала як твір синтетичний, як спроба інтегрувати художній досвід античності, українського фольклору та літератури, аби витворити якісно відмінну від попереднього часу літературну модель світу. Ця поема так само динамічна, як і час, коли вона виникла; тут багато зовнішнього руху, який виражається в сюжеті, діях і вчинках персонажів. Рух реалізує себе в мотиві подорожі, що відіграє в образній структурі твору не останню роль [2, с. 7-9].

Універсальне поняття того часу homo viator - людина, що йде, мандрівник. Його парадигма реалізується в конкретних явищах $\mathrm{i}$ постатях. В "Енеїді" представлені чи не всі типи мандрівних людей другої половини XVIII ст., номінативні означення яких часом нагромаджуються на незначній площі тексту: "Відкіль та се і гольтіпаки? / Чи рибу з Дону везете? / Чи, може, виходці-бурлаки? / Куди прочани ви йдете?" [5, с. 41].

Дослідники поеми спеціально не заглиблювалися ні в суть і значення в цьому творі мотиву подорожі, ні в характеристики типів мандрівних людей, обмежуючись загальними зауваженнями. Проте образи мандрівних людей у поемі не просто ілюструють певні типи, а розкривають особливості світогляду та естетичної програми письменника.

Еней - мандрівник, якого доречно було б порівняти з Одіссеєм. В інтерпретації Котляревського Еней поєднує в собі класицистичні риси особистості, чия доля регулюється усвідомленим обов'язком, з рисами ренесансної чуттєвості і плотської втіхи; та більше в цьому образі химерності, суперечливості й неоднозначності, що відповідає художнім 98 
параметрам барокового образотворення. Сам Котляревський по-різному називає свого героя: "парубок моторний і хлопець хоть куди козак", "завзятіший од всіх бурлак"; він у колі "гультіпак", прочан ("Енеєві прочани"), "ланців"; "провідця був по всіх содомах", "Еней пройдисвіт", "гульвіса" ("уздрів Енеєвих гульвіс") та ін. Застосування до Енея різноманітних найменувань-характеристик, які даються в тексті легко і невимушено, відповідає такому стильовому прийому в поемі, як градація: створення синонімічного ряду, у якому інваріант - homo viator. I тут вбачається вплив барокової естетики, згідно з якою зображуваний об’єкт міг поставати у множинності своїх внутрішніх і зовнішніх виявів.

По-різному названо i троянців: ланці, гольтіпаки, пройдисвіти, гульвіси, волоцюги. Ці характерні означення вживаються ніби жартома, певною мірою зі співчуттям і захопленням - в усякому разі, без негативного відтінку. У процесі травестування редукуються серйозність та строгість визначень, переінакшуються поняття, відбуваються семантичні зміщення, внаслідок чого твориться колоритне то для розгортання сюжету.

Дослідники поеми Котляревського відзначали зв'язок твору та окремих його персонажів із творчістю мандрівних дяків. Та говорячи про генетичну спорідненість пародій, орацій і травестій мандрівних дяків 3 "Енеїдою", можемо ствердити, що Котляревський створив у поемі тип мандрівника-митця-письменника. Але це не "скучнії піїти, писарчуки поганих вірш", а ті, кого надихає на творчість "весела, гарна, молодая" муза. Безперечно, автор мав на увазі мандрівних дяків, проте в поемі не натрапляємо на такий образ, а є лише окремі штрихи до нього: "мов 3 торгу в школу курохват" [5, с. 49] - порівняння Енея з бурсаками; "Еней (...) велів побігти до дяків купить Піярську граматку" [5, с. 110] підготовка послів до Латина нагадує звичай у давніх школах.

Котляревський інколи уподібнює троянців до чумаків за зовнішніми ознаками їх мандрівного життя. Для XVIII ст. постать чумака - досить характерна, тому невипадково в письменника виникали такі асоціації, коли він змальовував ватагу троянців: Невтеса "не раз ходив за сіллю в Крим, тарані торгував возами, всі чумаки братались з ним" [5, с. 65 -66].

Згадки про бурлак в поемі не мають за мету "реалістично" проілюструвати соціальне явище. Тип відносно вільної людини (в умовах закріпачення селян у XVIII ст.), тип "вихідців-бурлак" - селян, котрі покидали насиджені місця в пошуках вільних земель, тип "завзятого бурлаки" - це відповідало духові троянської ватаги і тому легко накладалося в поемі на образи обездолених, позбавлених рідного дому переселенців-мандрівників. 
Ще одна номінація травестованих троянців - прочани: "Куди, прочани, ви йдете?" [5, с. 41], "Енеєві прочни" [5, с. 125], "як тут сих поселить прочан" [5, с. 193] тощо. У структурі збірного образу троянців це означення також не випадкове, оскільки XVIII ст. в українському письменстві позначене активізацією паломницького жанру - завдяки пожвавленню паломництва загалом [3; 4]. Вживаючи назву "прочани", Котляревський вдається до семантичного зміщення, адже прочанин (паломник, пілігрим) - це мандрівник до святих місць, а троянці подорожують у пошуках придатної для осідку землі. Тож апеляція до прочанства - навмисне, довільне маніпулювання поняттям, яке завиграшки застосовується до інорідного явища. Водночас у контексті травестування виникає "вивернуте" поняття прощі: "Прямцем до пекла поплелися, пішли на прощу до чортяк" [5, с. 79]. У цій картині все поставлене 3 ніг на голову: проща не до святих місць, а до пекла; не до священних храмів, мощів святих чи до Гробу Господнього, а до "чортяк". Таке зміщення має своє виправдання у художньому сенсі, бо виводиться з барокової природи комічного.

До типів мандрівних людей можна віднести і зображених в "Енеїді" жебраків: "Се бідні нищі (...) старці, хромі, сліпорожденні (...) Се, що $з$ порожніми сумками жили голодні піж тинами (...) се ті, що Біг дасть получали, се ті, яких випроводжали в потилицю і по плечах" [5, с. 98]. Змальовуючи цих людей зі співчуттям і надаючи їм місце у раю (в описі пекла згадуються лише "волоцюги" i "мандрьохи"), Котляревський вказує на неодмінний компонент соціальної структури, а в художньому плані досягає контрастності у моделюванні морально-етичного тла людського світу. Тут не акцентується на тому, що серед "старців, хромих, сліпорожденних" часто були такі знакові постаті старої України, як лірники, кобзарі, бандуристи, "каліки перехожі", котрі репрезентували певні елементи народної культури, зокрема пісенної і сміхової.

Підсумовуючи, наведемо слова О. Білецького про персонажів "Енеїди": "Це людський світ (...) "пройдисвіти", розбійники, босяки - i водночас "лицарі, герої, титани"[1, с. 118]. Представлені у поемі типи мандрівних людей - характерна ознака реалістичного світу, а в художньому сенсі - зображення в "Енеїді" динамічного, суперечливого, неоднозначного, драматичного українського XVIII століття, що й породило таку естетичну свідомість, яка в особі Котляревського спромоглася вивести нашу літературу на нові художні простори, покласти початок новому українському письменству. 


\title{
Література:
}

1. Білецький О.І. Зібрання праць у 5 т. Т.2. Київ, 1965.

2. Білоус П.В. Мотив подорожі в "Енеїді" І.П. Котляревського. І.П. Котляревський - перший класик нової украӥнської літератури: зб. статей. Ч. ІІ. Полтава, 1998. С. 7 - 9.

3. Білоус П. В. Паломницький жанр в українській літературі. Житомир, 1997.

4. Білоус П.В. Творчість В. Григоровича-Барського. Київ, 1985.

5. Котляревський I. Поетичні твори. Драматичні твори. Листи. Київ, 1982.

DOI https://doi.org/10.30525/978-9934-26-073-5-1-25

\section{МОРАЛЬНО-ЕСТЕТИЧНІ ЦІННОСТІ ЕПОХИ ЗМІН У ЦИКЛІ «ZEITBILDER» А. ФОН ДРОСТЕ-ГЮЛЬСХОФ}

\author{
Білоус Н. В. \\ старший викладач кафедри іноземних мов \\ Таврійського державного агротехнологічного університету \\ імені Дмитра Моторного \\ м. Мелітополь, Запорізька область, Україна
}

Аннетте фон Дросте-Гюльсхоф (Annette von Droste Hulshoff, 1797-1848) є відомою письменницею та поетесою Німеччини ХIX ст. На сьогоднішній день творчість А. Дросте недостатньо проаналізовано вітчизняними, а в деяких аспектах - i зарубіжними вченими. Поетичний спадок видатної німецької поетеси маловідомий не тільки широкому колу читачів, а й навіть спеціалістам-філологам. Серед німецьких дростезнавців життя і творчість письменниці вивчали відомі германісти К. Буссе [1], К. Гезельгаус [2], В. Зільц [3], П. Берглар [4], В. Веслер [5], Ф. Зенгле [6], В. Геден [7], Р. Шнайдер [8]. Серед літературознавцівгерманістів інших країн слід відзначити студії Дж. Роллстона [9], Г. Пикар [10], А. Бакалова [11], О. Іванової [12]， Л. Колаго [13] та особливо нашого співвітчизника Б. Завідняка [14].

Одним з найбільш плідних періодів у творчості А. Дросте був кінець 1841 - початок 1842 року, коли було написано цикл «Zeitbilder» (у перекладі - «Картини епохи»). Представлений цикл $\epsilon$ серією $з$ десяти віршів, у яких авторка виявляє критичне налаштування на дискусіюбесіду зі своїми сучасниками. За допомогою новаторських текстів вона 